\title{
P02.01. A dietary approach for treating dyslipidemia and hyperglycemia
}

\author{
J Feuerstein ${ }^{1 *}$, L Bautista ${ }^{2}$, W Bjerke ${ }^{3}$ \\ From International Research Congress on Integrative Medicine and Health 2012 \\ Portland, Oregon, USA. 15-18 May 2012
}

\section{Purpose}

Elevated LDL cholesterol and impaired fasting glucose are significant risk factors for cardiovascular disease; the most prevalent cause of mortality in the USA. Many dietary approaches have been examined to help combat these medical problems. Each type of diet typically places a particular emphasis on the relative proportions of the three macronutrients; fat, carbohydrate and protein.

\section{Methods}

We report on a case series of 41 patients who were placed on an 1100-calorie diet reduced in starch and emphasizing lean proteins, mono and polyunsaturated fats and fiber with a unique composition of macronutrients for four months in an effort to improve cholesterol and fasting glucose indices.

\section{Results}

28 of the 41 (68\%) patients complied with the protocol over a four-month period. In the compliant group, statistically significant reduction $(\mathrm{p}<0.05)$ in the following mean variables were seen: Weight $(2.3 \mathrm{~kg})$, Total Cholesterol $22 \%$ (53 mg/dL), LDL 23\% (43 mg/dL), HDL (4 mg/dL), TAG $(21 \mathrm{mg} / \mathrm{dL})$ and fasting serum glucose $(12 \mathrm{mg} / \mathrm{dL})$, after 4 months on the dietary regimen. In the non-compliant/ comparison group, statistically significant increases $(\mathrm{p}<0.05)$ in the following variables were seen at the end of 6 months: Total Cholesterol $(24 \mathrm{mg} / \mathrm{dL}), \mathrm{LDL}(14 \mathrm{mg} / \mathrm{dL})$ and TAG $(29 \mathrm{mg} / \mathrm{dl})$.

\section{Conclusion}

This magnitude of reduction in Total and LDL Cholesterol is significantly greater than that seen in the recent large dietary intervention trials and is comparable to that seen

${ }^{1}$ Stamford Hospital, Columbia University, Stamford, USA

Full list of author information is available at the end of the article in the 'eco-Atkins' trial, which was far more restrictive in nature and shorter in duration.

\section{Author details}

'Stamford Hospital, Columbia University, Stamford, USA. ${ }^{2}$ Optimus Healthcare, Stamford, USA. ${ }^{3}$ Sacred Heart University, Fairfield, USA.

Published: 12 June 2012

doi:10.1186/1472-6882-12-S1-P57

Cite this article as: Feuerstein et al:: P02.01. A dietary approach for treating dyslipidemia and hyperglycemia. BMC Complementary and Alternative Medicine 2012 12(Suppl 1):P57.

Submit your next manuscript to BioMed Central and take full advantage of:

- Convenient online submission

- Thorough peer review

- No space constraints or color figure charges

- Immediate publication on acceptance

- Inclusion in PubMed, CAS, Scopus and Google Scholar

- Research which is freely available for redistribution

\section{(Ciomed Central}

